\title{
Fluoride in the drinking water of Pakistan and the possible risk of crippling fluorosis
}

\author{
M. A. Tahir and H. Rasheed \\ Pakistan Council of Research in Water Resources, Khayaban-e-Johar, H-8/1, Islamabad, Pakistan \\ Correspondence to: M. A. Tahir (pcrwr2005@yahoo.com)
}

Received: 3 February 2012 - Published in Drink. Water Eng. Sci. Discuss.: 7 September 2012

Revised: 21 December 2012 - Accepted: 24 January 2013 - Published: 21 February 2013

\begin{abstract}
To explore the possibility of fluoride toxicity, 747 water samples were collected from surface water and groundwater sources of 16 major cities of Pakistan, adopting a uniform sampling design with distribution of samples: Lahore (79), Kasur (46), Faisalabad (30), Khushab (50), Chakwal (51), Mianwali (30), Jhelum (53), Bahawalpur (60), Karachi (60), Mirpur Khas (55), Peshawar (38), Risalpur (35), Quetta (81), Ziarat (21), Loralai (21), and Mastung (37). Comparison of analytical findings with WHO Guidelines of Drinking Water for Fluoride (i.e., $1.5 \mathrm{ppm}$ ) has concluded that $16 \%$ of the monitored water sources have fluoride concentration beyond the permissible safe limit of $1.5 \mathrm{mg} \mathrm{L}^{-1}$ falling in the concentration range of $1.6-25 \mathrm{mg} \mathrm{L}^{-1}$. The highest fluoride contamination (22\%) is detected in the Balochistan province followed by $19 \%$ in Punjab province. Comparatively higher fluoride levels of $>20 \%$ in the groundwater sources like hand pumps supported the possibility of increased groundwater contamination as excessive fluoride concentrations are expected to come from calcium-poor aquifers and in areas where fluoride-bearing minerals are common or where cation exchange of sodium for calcium occurs. Field observations have also indicated the prevalence of fluoride-associated health implications in the study areas with excessive fluoride in water sources. Findings of this study have provided bidirectional vision for the epidemiological investigations as well as to mitigate the issues in the affected vicinities of fluoride-rich areas.
\end{abstract}

\section{Introduction}

Per capita water availability in Pakistan has decreased from $5000 \mathrm{~m}^{3}$ per annum in 1951 to 1100 , which is just above the internationally recognized scarcity rate. It is projected that water availability will be less than $700 \mathrm{~m}^{3}$ per capita by 2025 (Pak-SCEA, 2006). Recent estimations of the availability and use of groundwater of an acceptable quality have also indicated the heavy over-exploitation of the water resources resulting in the deteriorated quality as well as quantity of the groundwater (Pakistan Water Partnership, 2000). Findings of the several studies conducted in the country to have exact evaluation of the drinking water quality have disclosed the presence of a few potentially toxic substances in the groundwater with higher concentration accelerated by the human activities. The major reasons of poor water quality may be the untreated disposal of municipal and industrial effluents, excessive use of fertilizers and insecticides. In addition, out of the total, $40 \%$ of diseases prevalent in the country are waterborne and 20-40\% hospitalizations are due to such waterborne diseases (PCRWR, 2008). Therefore, considering the demand of the time, Pakistan Council of Research in Water Resources (PCRWR) launched a National Water Quality Monitoring Programme (2001-2006) in the country, and the findings of this mega-water quality monitoring program for 23 major cities of Pakistan have revealed the prevalence of four major water quality tribulations such as bacteriological contamination (68\%), arsenic (24\%), nitrate $(13 \%)$ and fluoride $(5 \%)$ in the surface or groundwater sources of Pakistan, specifically in the cities like Kasur, Loralai, Quetta, Bahawalpur, Karachi, Faisalabad and Ziarat (Kahlown et al., 2008).

Fluoride is an important water quality parameter and has beneficial effects on teeth at low concentrations in drinkingwater; however, excessive exposure to fluoride in drinkingwater, or in combination with exposure to fluoride from other 
sources, can give rise to a number of adverse effects, which may range from mild dental fluorosis to crippling skeletal fluorosis as the level and period of exposure increases. Many countries in the world, especially Iraq, Iran, Syria, Turkey, India, Algeria, Morocco, Southern Parts of the USA and former USSR, have also reported the higher fluoride concentration in their groundwater (Edmunds and Smedley, 1996 and Mangla, 1991).

Khan et al. (2002) have investigated the presence of fluoride in drinking water of Lahore city within safe limits; however, adjoining areas like Mangamandi with higher fluoride concentrations in the water sources have also reported health effects like dental and skeletal fluorosis among the natives due to excessive fluoride intake through drinking water (Khan et al., 2002). Similar case was reported in the groundwater of Mastung valley in Kalat division of Balochistan province (A. Khan, unpublished data, 1999).

Considering the potential toxicity of higher fluoride concentration appeared as dental or skeletal fluorosis, Pakistan Council of Research in Water Resources with financial assistance from United Nation's Children Education Funds (UNICEF) carried out a detailed investigation on prevalence of fluoride in drinking water sources of 16 major suspected cities of Pakistan, and the main objectives of the study were to authenticate the reported levels of fluoride and to review the possible associated health implications to be disseminated to implementing agencies in order to provide guidelines to the affected communities for locating alternate safe water sources.

\section{Materials and methods}

Seven hundred and forty-seven (747) water samples were collected from various surface or groundwater sources such as hand pumps, tube wells, wells, nullahs, springs, dams, bores and water supply of 16 major cities of the country on the basis of grid size of $0.25 \mathrm{~km}^{2}$ for small cities, $9 \mathrm{~km}^{2}$ for medium cities and $16 \mathrm{~km}^{2}$ for big cities as given in Table 1 .

Following the grids on the city maps, one sample per grid was taken maintaining a distance of 0.5 or $1 \mathrm{~km}$ between two monitoring points. Replicating every fifth sample for quality control purposes, 298 samples were collected additionally to check the reliability and accuracy of the sampling and analytical procedures.

Following the standard methods, all the samples were collected in $0.5 \mathrm{~L}$ polystyrene bottles and transported to laboratory in the least possible time (APHA-AWWA-WEF, 1992). Field information regarding sampling was recorded on the sampling pro forma. All the samples were analyzed for fluoride $\left(\mathrm{mg} \mathrm{L}^{-}\right)$using SPANDS method recommended by standard methods based on the comparatively higher sensitivity and efficiency of the method (APHA-AWWA-WEF, 1992). A sample of blank, known fluoride standard and previously analyzed sample were analyzed after every ten samples to
Table 1. Sampling criteria and no. of samples collected from four provinces of country.

\begin{tabular}{cllcc}
\hline $\begin{array}{c}\text { Sr. } \\
\text { No. }\end{array}$ & Province & City & $\begin{array}{c}\text { Grid Size } \\
\left(\mathrm{km}^{2}\right)\end{array}$ & $\begin{array}{c}\text { No. of } \\
\text { Samples }\end{array}$ \\
\hline 1 & Punjab & Lahore & 3 & 79 \\
& & Kasur & 0.5 & 46 \\
& & Faisalabad & 3 & 30 \\
& & Khushab & 0.5 & 50 \\
& & Chakwal & 0.5 & 51 \\
& & Mianwali & 0.5 & 30 \\
\hline 2 & Sindh & Jhelum & 0.5 & 53 \\
& & Bahawalpur & 3 & 60 \\
\hline 3 & North West Frontier & Karachi & 4 & 60 \\
& Province (NWFP) & Pirpur Khas & 0.5 & 55 \\
\hline \multirow{2}{*}{4} & Balochistan & Risalpur & 3 & 38 \\
& & Quetta & 1.5 & 81 \\
& & Ziarat & 0.5 & 21 \\
& & Loralai & 0.5 & 21 \\
& & Mastung & 0.5 & 37 \\
\hline \multirow{3}{*}{} & & Grand Total & - & 747 \\
\hline
\end{tabular}

check the reproducibility of method, and their results were found in the range of $\pm 5 \%$ deviation compared to the actual analysis.

\section{Results and discussion}

Analytical findings were compared with WHO Drinking Water Guideline value for fluoride, which also considers the impact of climatic conditions, volume of water intake as well as fluoride intake from other sources (WHO, 2004). Thus, considering the annual average of maximum daily air temperature $\left(84^{\circ} \mathrm{F}\right)$ of Pakistan, WHO guideline value for fluoride in the drinking water of Pakistan is considered as $1.5 \mathrm{mg} \mathrm{L}^{-}$. City-wise status of fluoride as percentage contamination, out of total monitored sites of each city, is graphically reflected in Fig. 1. Mianwali city has shown the highest contamination level of $37 \%$ in Punjab province, Mirpur Khas city (3.6\%) in Sindh province, Quetta city $(14 \%)$ in Balochistan province and Risalpur city (11\%) in North-West Frontier Province (NWFP).

Overall, only $16 \%$ samples out of total 747 were found to be unsafe, whereas the remaining $84 \%$ were declared to be safe. This overall distribution of fluoride for 747 locations monitored in selected 16 cities is shown as Fig. 2.

Table 2 provides details of quantitative summaries of each water quality variable, namely the minimum, maximum, median (middle value of the ordered data), mean, the first and third quartiles, $Q 1$ and $Q 3$, respectively (which are the 25th and 75th percentile values of the ordered data), and the total number of observations recorded (Count). Comparing 


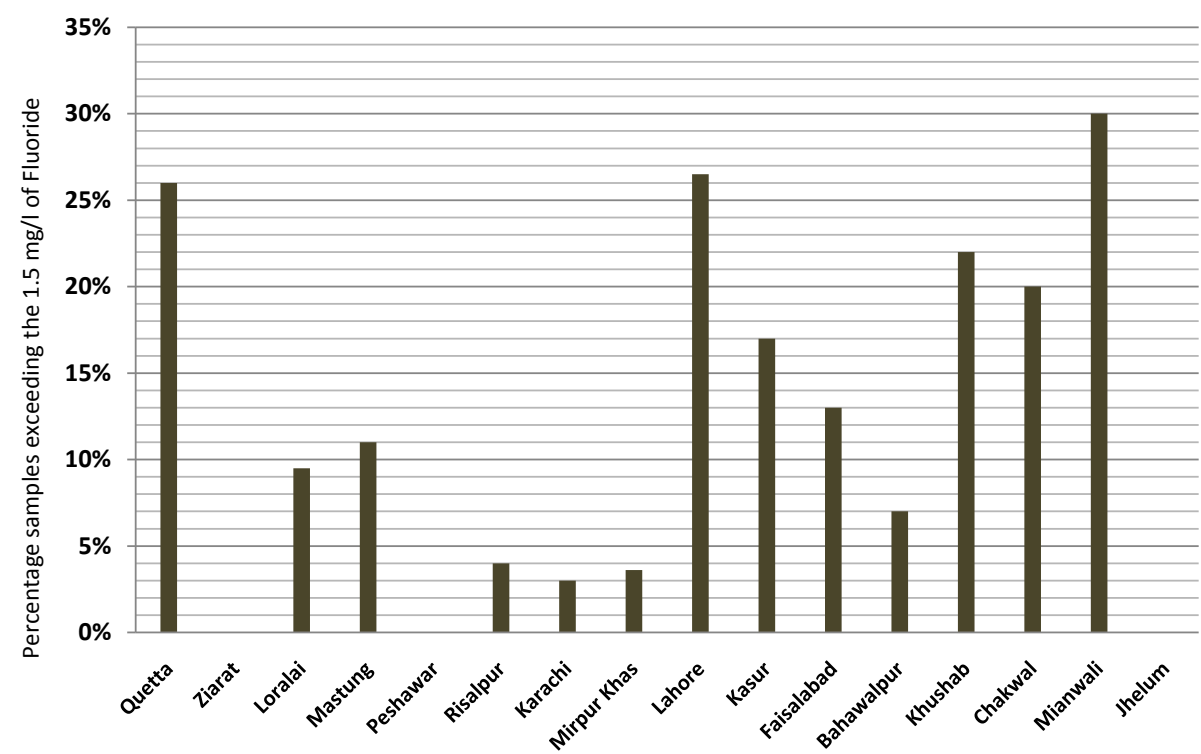

Figure 1. Distribution of fluoride in 16 cities of four provinces.

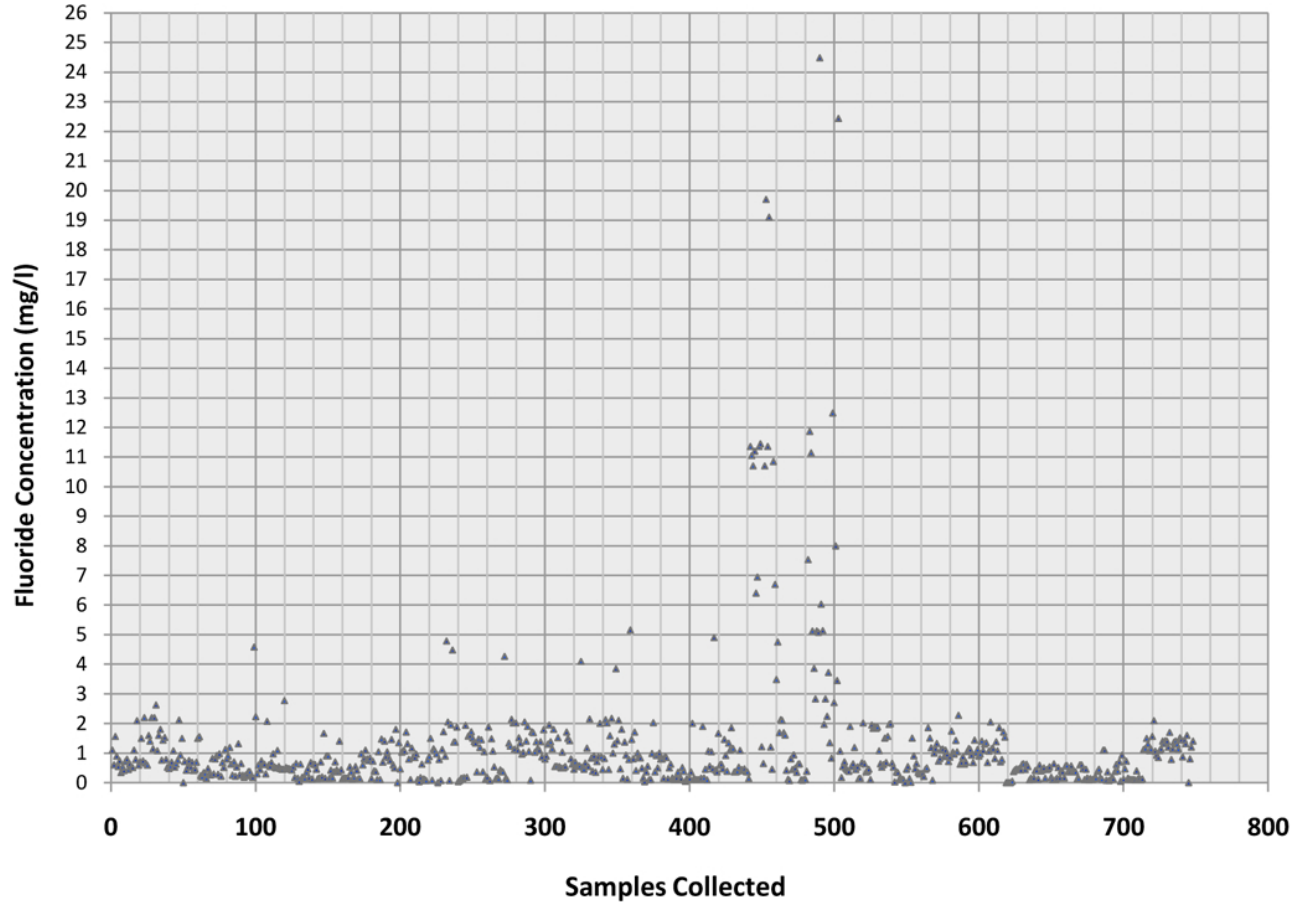

Figure 2. Variation of fluoride concentration $\left(\mathrm{mg} \mathrm{L}^{-1}\right)$ in the monitored sites.

means and medians, we see that the means of fluoride are substantially greater than their medians (except for Jhelum city). The distributions of the data for these variables are highly skewed to the right.

An overall comparison of four provinces indicated a higher percentage contamination in Balochistan province followed by Punjab province. The province-wise distribution is also given in Figs. 3-6 to provide an idea of range of fluoride concentration within each province.

The results of this perspective survey have finally led to recognition of the fact that fluoride is a considerable issue in a few places of Pakistan. Observations of the sampling team have also disclosed the possible signs and symptoms including skeletal and dental fluorosis among the few individuals of the communities associated most probably with the excessive 
Table 2. Basic statistics of fluoride in water sources of 16 cities.

\begin{tabular}{llcccccccc}
\hline Sr. No. & Cities & Count & Mean & SD & Min & $Q 1$ & Median & $Q 3$ & Max \\
\hline 1 & Chakwal & 51 & 1.02 & 0.60 & 0.00 & 0.59 & 0.76 & 1.49 & 2.63 \\
2 & Bahawalpur & 60 & 0.67 & 0.67 & 0.15 & 0.30 & 0.53 & 0.74 & 4.58 \\
3 & Karachi & 60 & 0.48 & 0.44 & 0.05 & 0.17 & 0.43 & 0.54 & 2.77 \\
4 & Mirpur Khas & 55 & 0.74 & 0.48 & 0.00 & 0.28 & 0.81 & 1.06 & 1.80 \\
5 & Khushab & 50 & 1.09 & 1.10 & 0.04 & 0.16 & 1.05 & 1.50 & 4.78 \\
6 & Mianwali & 30 & 1.37 & 0.47 & 0.08 & 1.06 & 1.36 & 1.77 & 2.14 \\
7 & Kasur & 46 & 1.11 & 0.84 & 0.35 & 0.54 & 0.81 & 1.47 & 4.10 \\
8 & Faisalabad & 30 & 0.89 & 0.97 & 0.04 & 0.36 & 0.79 & 1.00 & 5.16 \\
9 & Lahore & 79 & 2.62 & 4.46 & 0.05 & 0.26 & 0.51 & 1.76 & 19.70 \\
10 & Quetta & 81 & 2.47 & 4.23 & 0.03 & 0.45 & 0.94 & 2.11 & 24.48 \\
11 & Ziarat & 21 & 0.39 & 0.33 & 0.01 & 0.14 & 0.34 & 0.47 & 1.51 \\
12 & Loralai & 21 & 1.08 & 0.38 & 0.08 & 0.88 & 1.04 & 1.18 & 1.86 \\
13 & Mastung & 37 & 1.13 & 0.41 & 0.63 & 0.82 & 1.08 & 1.35 & 2.27 \\
14 & Jhelum & 53 & 0.37 & 0.18 & 0.05 & 0.16 & 0.41 & 0.50 & 0.64 \\
15 & Peshawar & 38 & 0.29 & 0.29 & 0.05 & 0.10 & 0.15 & 0.40 & 1.10 \\
16 & Risalpur & 35 & 1.27 & 0.27 & 0.78 & 1.12 & 1.30 & 1.42 & 2.09 \\
\hline
\end{tabular}

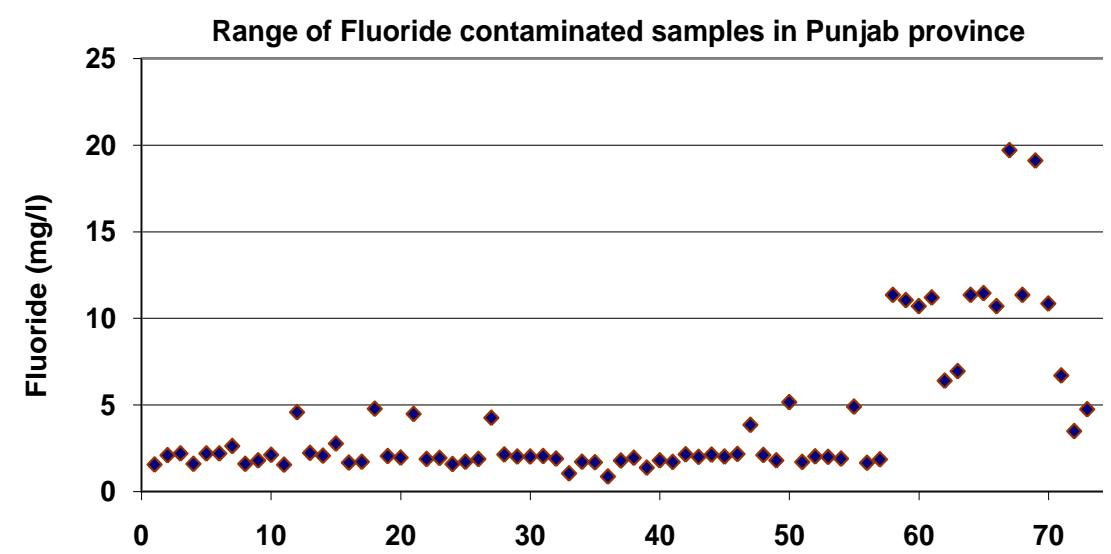

Figure 3. Range of fluoride-contaminated samples $\left(>1.5 \mathrm{mg} \mathrm{L}^{-1}\right)$ in Punjab province.

fluoride level in their drinking water. In the same way, deaths of the native people at locations with excessive fluoride due to an unknown chronic disease symptomized by bone and joint deformities have also been reported by teams of World Health Organization (WHO) and other NGOs in the year 2000. Experts found prominent signs of "dental fluorosis" in the native areas, where the possibility of chronic fluoride toxicity was confirmed further by the epidemiological and laboratory investigation in the problem areas by a joint team of Pakistan Council of Research in Water Resources (PCRWR), World Health Organization (WHO), National Institute of Health (NIH), and Federal Ministry of Health and Sindh Provincial Health Department in the year 2005.

Fluoride is unlikely to produce crippling skeletal fluorosis leading to osteosclerosis, ligamentous and tendinous calcification, hypersensitivity and other immunological effects (USNRC, 1993). In addition, fluoride has an effect on the kidneys, muscular and nervous system, and there are some reports about the relationship between erythrocyte abnormalities and serum fluoride levels with excessive fluoride intake and therefore leading to death after prolonged illness. Prolonged exposure to $10-20 \mathrm{mg}$ fluoride/person/day for $10-20 \mathrm{yr}$ can lead to crippling skeletal fluorosis, leading to osteosclerosis, ligamentous and tendinous calcification and extreme bone deformities (USNRC, 1993). Health impacts from long-term use of various ranges of fluoridated water have been summarized as the following:

$<0.5 \mathrm{mg} \mathrm{L}^{-1} \quad$ Dental caries;

$0.5-1.5 \mathrm{mg} \mathrm{L}^{-1} \quad$ Promotes dental health;

$1.5-4 \mathrm{mg} \mathrm{L}^{-1} \quad$ Dental fluorosis;

$>4 \mathrm{mg} \mathrm{L}^{-1} \quad$ Dental, skeletal fluorosis;

$>10 \mathrm{mg} \mathrm{L}^{-1} \quad$ Crippling fluorosis.

Fluoride in drinking water increases the risk of hip fractures in women as evidence has suggested that fluoride may be associated with some gender-dependent mechanisms 


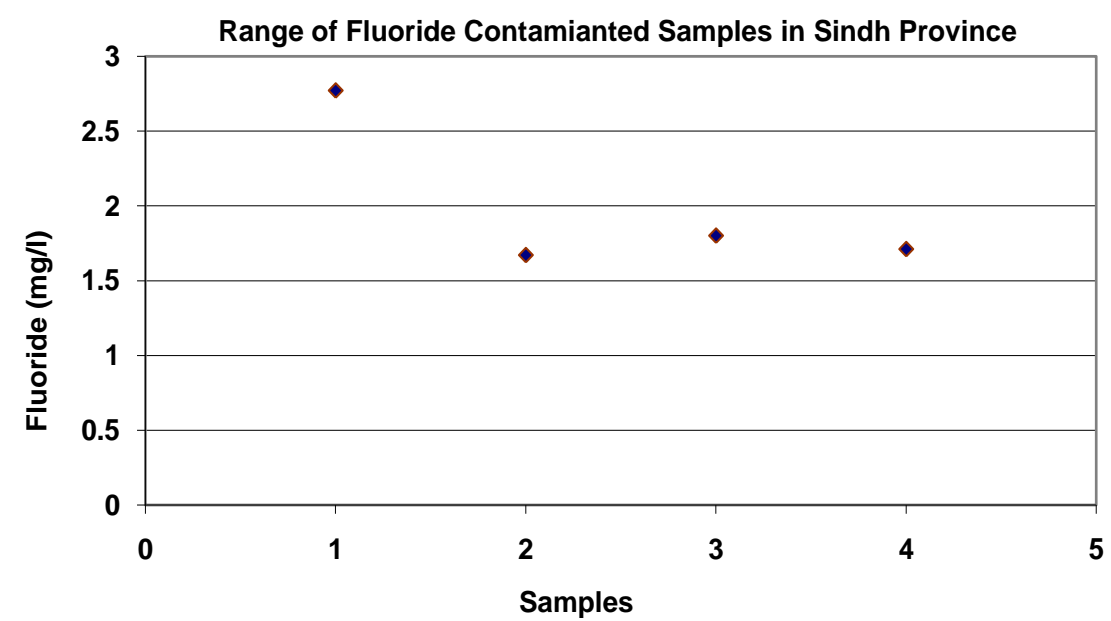

Figure 4. Range of fluoride-contaminated samples $\left(>1.5 \mathrm{mg} \mathrm{L}^{-1}\right)$ in Sindh province.

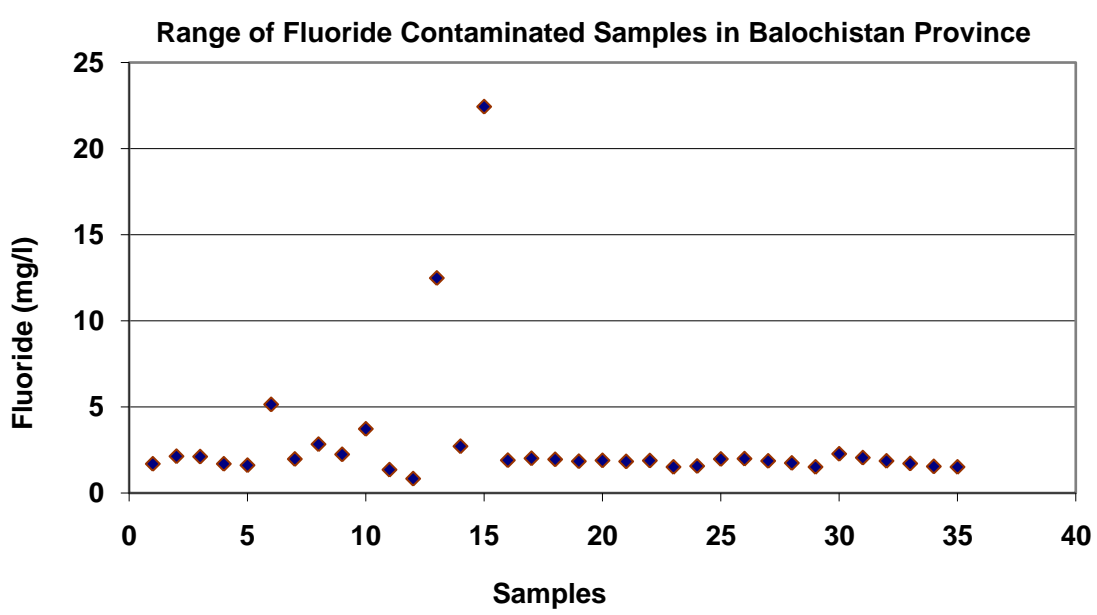

Figure 5. Range of fluoride-contaminated samples $\left(>1.5 \mathrm{mg} \mathrm{L}^{-1}\right)$ in Balochistan province.

or risk factors for hip fractures (Kurttio et al., 1999). A large number of epidemiological studies showed that fluoride is carcinogenic, a bone seeker and is associated with hip fractures and brittle bones (Yelena et al., 2001). It has also been found that the crippling malady of fluorosis affects not only the bones and teeth, but every tissue and organ of the body, leading to death after prolonged illness (Susheela et al., 1992). USNRC has concluded that fluoride is unlikely to produce hypersensitivity and other immunological effects. Fluoride is mainly excreted from the kidneys (USNRC, 1993). Thus, it is reasonable that those with impaired renal function might be at greater risk of fluoride toxicity than others. However, there is much evidence that the amount of fluoride absorbed and retained by the body is mainly dependent on nutrition, especially for children. The study mentioned has clearly indicated that most of the water sources of the 16 cities of the country are found free from the presence of excessive fluoride and therefore from the possibility of potential fluoride toxicity. In total, 16 locations have fluoride level $>10 \mathrm{mg} \mathrm{L}^{-1}$, which are suspected to have cases of crippling fluorosis and need detailed epidemiological study. Analytical findings of Balochistan and Punjab provinces give rise to the prediction that fluoride is more commonly found in the groundwater as depicted graphically in Fig. 7. However, detailed monitoring of the contaminated regions and surroundings is highly recommended to formulate a mitigation strategy.

Most of the fluoride found in groundwater is naturally occurring from the breakdown of rocks and soils or weathering and deposition of atmospheric volcanic particles. Fluoride can also come from runoff and infiltration of chemical fertilizers in agricultural areas, septic and sewage treatment system discharges and liquid waste from industrial sources. Pakistan is an agricultural country, and $96 \%$ of its total water resources are being used by agriculture sector. Fertilizer consumption has increased threefold during the past $30 \mathrm{yr}$ in the country. It reached one million nutrient tonnes in 1980 1981, two million tonnes in 1992-1993 and three million 


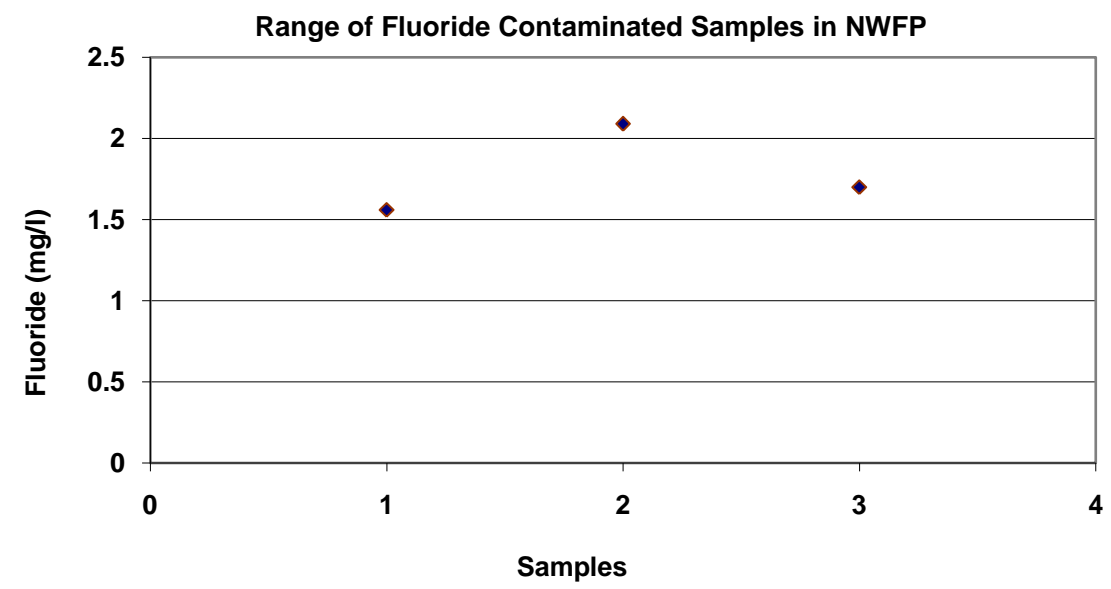

Figure 6. Range of fluoride-contaminated samples $\left(>1.5 \mathrm{mg} \mathrm{L}^{-1}\right)$ in NWFP.

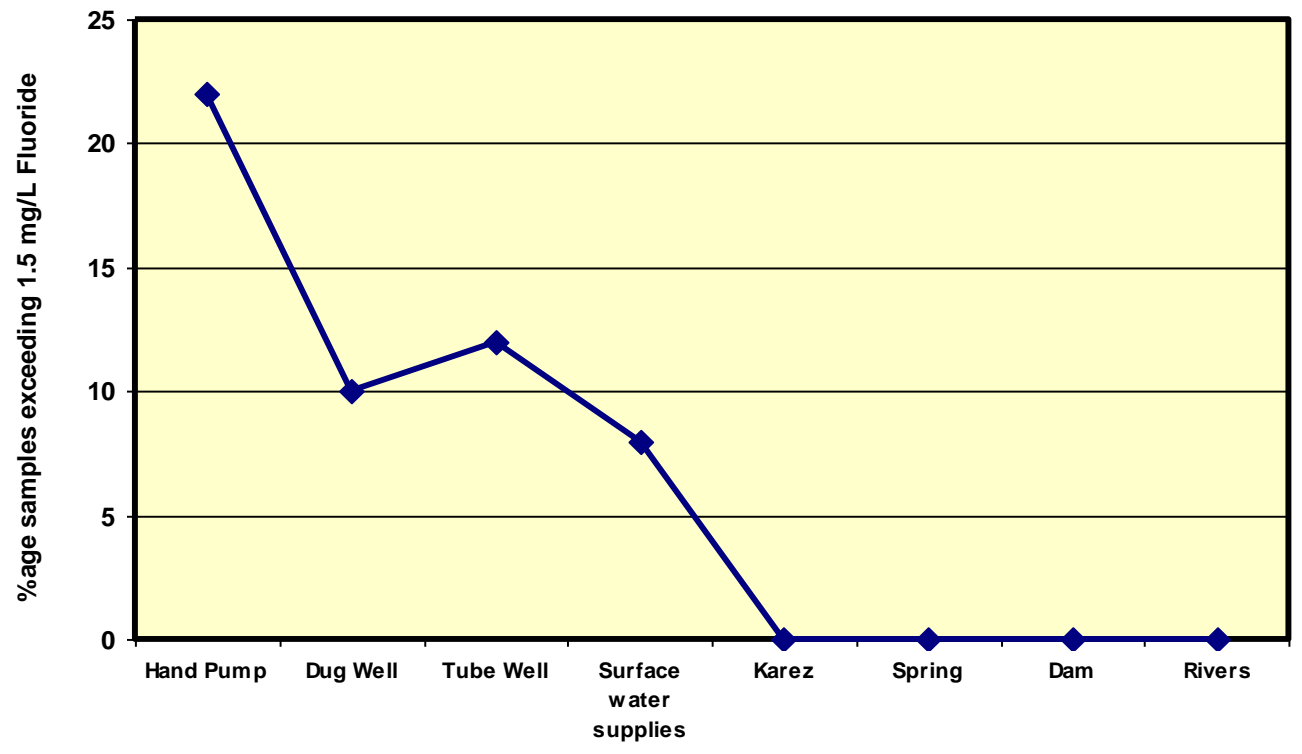

Types of water sources monitored

Figure 7. Distribution of fluoride in surface and groundwater sources.

tonnes in 2002-2003 and thus may be an important contributing factor of increased fluoride contamination (FAO, 2007). Moreover, fluorides are found at significant levels in a wide variety of minerals, including fluorspar, rock phosphate, cryolite, apatite, mica, hornblende and others (Murray, 1986). Fluorite $\left(\mathrm{CaF}_{2}\right)$ is a common fluoride mineral of low solubility occurring in both igneous and sedimentary rocks. Rock phosphates are converted into phosphate fertilizers by the removal of up to $4.2 \%$ fluoride (Murray, 1986). In groundwaters, however, low or high concentrations of fluoride can occur, depending on the nature of the rocks and the occurrence of fluoride-bearing minerals. Concentrations in water are limited by fluorite solubility, so that in the presence of $40 \mathrm{mg} \mathrm{L}^{-1}$ calcium it should be limited to $3.1 \mathrm{mg} \mathrm{L}^{-1}$ (Hem, 1989). Balochistan province of Pakistan is rich in mineral de- posits and diverse mineralogy, and in this region higher fluoride concentrations may therefore be expected in groundwater from calcium-poor aquifers and in areas where fluoridebearing minerals are common. Fluoride concentrations may also increase in groundwater in which cation exchange of sodium for calcium occurs. High groundwater fluoride concentrations associated with igneous and metamorphic rocks such as granites and gneisses have been reported from India, Pakistan, West Africa, Thailand, China, Sri Lanka, and southern Africa. In China, endemic fluorosis has been reported in all 28 provinces, autonomous regions and municipalities except Shanghai. Both shallow and deeper groundwater is affected; in general the deeper groundwaters have the higher concentrations. To cover up the gaps, institutional arrangements, capacity building efforts, legislations and policy 
development with reference to water quality monitoring and surveillance activities as well as diagnosis and management of water-related diseases are highly required to be managed in order to resolve the water quality problems like excessive fluoride and possible health implications.

Acknowledgements. We would like to gratefully acknowledge the contributions of technical and non-technical staff of National Water Quality Laboratory, PCRWR involved in sampling, laboratory analysis and coordination. The authors are grateful to Muhammad El-Feteh and Tameez Ahmad from WES Programme UNICEF Pakistan for financial assistance for the study.

Edited by: A. Mittal

\section{References}

APHA-AWWA-WEF: Standard methods for the examination of water and wastewater, American public health association, American water works association and water environment federation, 18th Edn., Washington, DC, 1-33:4-82, 1992.

Edmunds, W. M. and Smedley, P. L: Groundwater geochemistry and health: an overview, in: Environmental geochemistry and health, edited by: Appleton, J. D., Fuge, R., and McCall, G. J. H., Geological society special publication No. 113, 91-105, 1996.

FAO: The Fertilizer sector, in: FAO corporate document repository, http://www.fao.org/docrep/007/y5460e/y5460e07.htm\# TopOfPage (last access: 15 December 2004), 2007.

Hem, J. D.: Study and interpretation of the chemical characteristics of natural water, Water Supply Paper 2254, 3rd Edn., US Geological Survey, Washington, D.C., 263 pp., 1989.
Kahlown, M. A., Tahir, M. A., and Hifza, R.: Water Quality Status of Pakistan, Pakistan Council of Research in Water Resources, Islamabad, Pakistan, Technical report Series 121-2008, 79-80, 2008.

Khan, A. A., Whelton H., and O'Mullane, D.: Map of natural fluoride in drinking water of Pakistan, Int. Dent. J., 52, 7-10, 2002.

Kurttio, P. N., Gustavsson, N., Vartiainen, T., and Pekkanen, J.: Exposure to natural fluoride in well water and hip fracture: A cohort analysis in Finland, Am. J. Epidemiol., 150, 817-824, 1999.

Mangla, B.: India's dentists squeeze fluoride warnings off tubes, New Sci., 131, p. 16, 1991.

Murray, J. J.: Appropriate use of fluorides for human health, World Health Organization, Geneva, 1986.

Pak-SCEA: Pakistan; Strategic country environmental assessment report: Rising to the challenges, South Asian Development and Social Development Unit, the World Bank, 50 pp., 2006.

Pakistan Water Partnership: Framework for action for achieving the Pakistan water vision 2025, Islamabad, 2000.

Susheela, A. K., Das, T. K., Gupta, I. P., Tandon, R. K., Kacker, S. K., Ghosh, P., and Deka, R. C.: Fluoride ingestion and its correlation with gastro - intestinal discomfort, Journal Fluoride, 25, 7-12, 1992.

USNRC: US National Research Council, Health effects of Ingested fluoride, National Academy Press, Washington, D.C., 1993.

WHO: World Health Organization, Guideline for Drinking-Water Quality, 2nd Edn., Vol. 2, Health criteria and other supporting information, World Health Organization, Geneva, 2004.

Yelena, V., Marina, T., Viktor, A., and Rein, M.: Fluoride in drinking water, Tallinn Technical University, Estonia, 2001. 